\title{
Determinants of Tendency to Deviant Social Identity among Delinquent Youth
}

\author{
Hossein Afrasiabi \\ Assistant professor of Sociology, Yazd University
}

\begin{abstract}
Deviant identity has been recognized as one of the main causes of the crime in a large number of the studies. Formation of criminal or deviant identity are affected by different social conditions this study was conducted in order to investigate the factors underlying the deviant identity among the delinquent youth. The research sample consisted of 15-25years old delinquent youth in Yazd city. A survey was used as research method and data were collected using the questionnaires. The results showed that destructive social capital, Anomie and deviance in the family, have a significant relationship with deviant identity.
\end{abstract}

Keywords: Deviant Identity, Social Capital, Anomie, Family, Crime.

\section{Introduction}

The concept of deviant identity has been defined by the researchers in different ways. Some defined it as exiting an ordinary life style (Irwin, 1977; Lofland, 1969; Meisenhelder, 1977; Shover, 1983). Others argued that the deviant people never abandon their former identity and select a new role (Ebaugh, 1988). Labeling perspective considers the deviant identity as a factor that prevents the labeled deviant people enter the society (Sampson \& Laub, 1997; Link, 1982; Lemert, 1972; Becker, 1963).

The formation of criminal or deviant identity and having such a self-definition are affected by different social conditions. As Stryker emphasized in theory of identity salience, as much as a person has a salient identity, s/he plays those roles that are related to the functional expectations of their identity. In this way, s/he regards all situations as the opportunities for improvement and implementation of the identity and seek to find (or provide) those opportunities that are relevant for expression of identity (Turner, 2003).

Deviant identity has been addressed in many studies as one of the most important factors of the criminal actions. For example, Walters (2016) in his study concluded that the deviant identity predicts the deviant thinking and delinquency. Deviant identity has a major role in the growth of antisocial personality. This has been considered in other studies, too (Thompson, 2009; Watson, 2007; Matsueda, 1992). A variety of studies has been carried out on the factors related to deviant identity; Fergusson et al. (2007) concluded that relationship with deviant friends and destructive social capital leads to deviant behavior. Boduszek et al. (2012) showed that criminal relationships with close friends and inadequate supervision of parents have a direct effect on social or identity. Rocheleau and Chavez (2014) found that deviant peers strengthen labeling and deviant identity of the people.

One of the fundamental effects of the family can be observed on the identity formation of the children. A number of scholars believe that family factors and deviant family leads to the deviant identity of the children. Shaw et al. (1991) and Simons et al. (1991) regard the lack of affection and poor parenting practices as a factor in creating deviant identity. Vazsonyi and Belliston (2007) in their study showed that family processes have direct and indirect effect on the deviation of the people. The results of the study conducted by Abigatil et al. (2010) indicated that family factors lead to the tendency of children towards crime and deviance. Studies have also been conducted on the anomie and deviation; Zojonc (2013) showed that there is a significant relationship between anomie and deviance and crime. Carter and Carter (2014) concluded that anomie caused a further deviation. Noriega et, al (2014) showed that anomie increases the criminal behaviors.

There are a high number of people who have a criminal record with different repeated social deviations. On the other hand, living and interactions can shape and strengthen this deviant identity. This study followed the question that Which variables are related to the acceptance of deviant identity? 


\section{Theoretical Background}

The theoretical framework draws from the theory of interaction, differential association and Merton's theory of anomie. Among the different theories that have been raised in explaining the social deviations, symbolic interaction approach mainly focuses on the self and identity and emphasizes that formation of deviant interaction has a bilateral relationship with self and identity; especially since the commission of deviancy and its social outcomes influence on the formation of deviant identity. Last but not least, identity, as a social concept, has been mainly developed in the framework of interaction. Concerning the crime, symbolic interaction theorists believe that individual self-concept as a deviant or law-abiding person is formed through the development of functionality processes and social interactions (Matsueda, 1992; Thornberry, 1987). Once this process is repeated over time, deviant identity and improving the functional commitment and social relations in the network increase (Stryker \& Burk, 2000).

One of the views consistent with the views of social identity is the theory of differentiation proposed by Sutherland in relation to social deviations. He believes that deviant behavior, like other social behaviors are learned through companionship and association with others (Sutherland \& Cressy, 1966: 170). According to this theory, the greater the individual's relationship with deviant individuals, it can be the basis for strengthening the deviant identity of the people. From this perspective, the formation of deviant identity above all is the result of social interactions with individuals, groups and environments that are involved in criminal behavior and deviation. In these situations, people learn that deviation is a natural and normal part of the individual life and therefore, they try to appeal it for solving their problems. Gradually as the interaction and contact with deviant people increases, individual deviant identity is strengthen, too. Of course, these interactions in contemporary sociology literature can be mainly raised in relation to the concept of "social capital". Hutter and Smith conducted a study on released prisoners and found that social capital is one of the most important factors for re-entering the prison. They stated that having high social capital faciliates accessing to important resources such as jobs and housing that are two important variables to connect the people and society (Hattery \& Smith, 2010: 101).

Merton believes that anomie and some forms of abnormal behavior mainly result from separation of the cultural institutional goals of a society and social ways to achieve those objectives. In other words, the gap between goals and legitimate means to achieve them lead to failure in individual and social values (Garfield, 1987: 272). The main assumption of this theory is that market mechanisms and regulations cause anomic stresses. Market strengthens the materialistic views on social relations. When these trends will continue, probably anomie occurs. When the objectives are promoted by cultural support, while the controller normative tools lose continuous effect, conditions for the anomic activities are provided. In an anomic environment, activists are engaged with the results and efficiency of the action, not the legitimacy of tools that helps regulate behavior. Normative control failure likely increases the amount of improper behaviors such as crime and deviance (Messner, S., Rosenfeld, 1997: 936).

According to Sutherland, in fact, destructive social capital leads to a kind of deviant identity; because people try to mimic the deviant behaviors and as this relationship continues, this deviant identity is strengthened. On the other hand, according to the symbolic interaction, family is the most important place where individual functionality is shaped; therefore, any kind of the deviancy in family, lead to deviant behaviors and since these people tend to communicate with deviant groups, the network of their relationships create a destructive social capital.

Also according to Merton, anomic conditions and undermining the normative control, will lead to the deviant behaviors; so, anomic conditions may shape the destructive social capital; so, based on the theoretical framework, research model is outlined as follows:

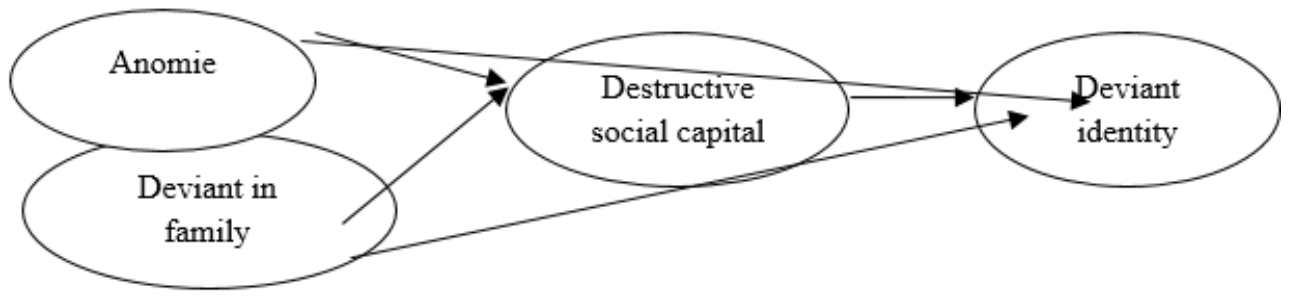

Figure 1: Theoretical model 


\section{Methods}

\section{Participants and Method}

This is an applied research survey. The Statistical population consists of all youth delinquents in the rehabilitation of Yazd City-Iran, of whom 381 were selected using the Cochran formula; statistical samples were obtained using systematic random sampling; a list was prepared and respondents were selected using the sampling ratio.

\section{Scales}

Researcher-developed questionnaire was used for data collection. Answers were scored based on the Likert scale. The face validity and reliability of the questionnaire was measured using Cronbach's alpha. The questionnaire had two parts. The first part included demographic and descriptive variables such as gender, age, type of crime and recidivism rate and the second part included the dependent variable (identity deviation) and independent variables (anomie, destructive social capital and deviation in the family).

Table 1. Operational definition and reliability of research variables

\begin{tabular}{|c|c|c|}
\hline Variable & Items & Cronbach's alpha \\
\hline Deviant identity & $\begin{array}{l}\text { 1. To what extent do you feel comfortable with positive and healthy people? } 2 \text {. To what } \\
\text { extent are you accustomed to the criminal life? } 3 \text {. To what extent are you proud of } \\
\text { being an offender? } 4 \text {. To what extent do you enjoy relationship with offender friends? } 5 \text {. } \\
\text { To what extent do you know yourself as a professional criminal? } 6 \text {. To what extent do } \\
\text { you sympathize with the other prisoners? } 7 \text {. To what extent do you help a criminal, if he } \\
\text { wants to? } 8 \text {. To what extent do you get upset, if others recognize you as a criminal? } 9 . \\
\text { To what extent do you get relaxed by offending? 10. To what extent do you feel you } \\
\text { were born an offender? 11. To what extent do you think you are a successful person in } \\
\text { wrongdoing? 12. To what extent do you feel intimate with offenders? 13. To what } \\
\text { extent do you regret after wrongdoing? 14. To what extent do you think criminals are } \\
\text { better people? }\end{array}$ & 0.82 \\
\hline Deviance in the family & $\begin{array}{l}\text { To what extent do these behaviors exist among your family members? : 1. Drug abuse. } \\
\text { 2. Alcohol consumption. } 3 \text {. Fights and clashes at home. } 3 \text {. Fights and clashes outside } \\
\text { the family. } 4 \text {. Judicial sentence. }\end{array}$ & 0.80 \\
\hline $\begin{array}{l}\text { Destructive social } \\
\text { capital }\end{array}$ & $\begin{array}{l}\text { How much do you spend your leisure time with your deviant friends? To what extent do } \\
\text { you consult with your deviant friends? To what extent do you have intimate } \\
\text { relationships with your deviant friends? To what extent do you talk about your problems } \\
\text { with your deviant friends? To what extent do you trust these people? } \\
\text { deviant friends } \\
\text { prison mates } \\
\text { deviant people in your locale }\end{array}$ & 0.80 \\
\hline
\end{tabular}

\section{Results}

Out operating time 381 respondents, $84 \%$ were men and $16 \%$ were women. $62.7 \%$ were prisoned once, 17.1 twice, $8.9 \%$ three times, $5.2 \%$ four times, $2.9 \%$ five times and $2.1 \%$ were prisoned more than five times. In terms of crime, $67.6 \%$ were prisoned for drug, $8.4 \%$ for theft, $2.4 \%$ for murdering, $3.2 \%$ for beatings, $4.9 \%$ for financial crimes and $13.5 \%$ were prisoned for other crimes.

Table 2. Profiles of respondents

Variable

Gender

Times of imprisonment

$\begin{array}{ll}\text { Items } & \text { Percentage } \\ \text { Male } & 84 \\ \text { Female } & 16 \\ \text { 1 Time } & 62.7 \\ \text { 2 Time } & 17.1 \\ \text { 3 Time } & 8.9 \\ \text { 4 Time } & 5.2 \\ \text { 5 Time } & 2.9\end{array}$


The results in Table 2 show that the deviant identity has a positive and significant relationship with destructive social capital $(r=295 ; P<0.01)$. Moreover, there is a significant relationship between anomie and deviant identity $(r=237 ; P<0.01)$. There is a positive and significant relationship between deviant identity and deviations in the family $(r=231 ; P<0.01)$.

Table 3. Correlations Matrix

1

1. Deviant identity

2. Destructive social capital

3. Anomie

4. Deviant in family
1

$.295^{* *}$

$.237^{* *}$

$.150^{\star *}$

$.157^{* *}$

.058
1

Note: ${ }^{* *}$ Correlation is significant at the 0.01 level (2-tailed)

\section{Path analysis}

Path model was obtained using Amos Software version 22. Fitting indices show that the model has a relative good fitting; Chi Square was 1.28 that is desirable. RMESA value should backup less than 0.05 that is 0.027 in the proposed model. The values of the components of $\mathrm{CFI}, \mathrm{NFI}, \mathrm{NNFI}, \mathrm{IFI}$, and $\mathrm{GFI}$ were $0.99,0.98,0.97,0.99$ and 0.99 , respectively that shows the good fitting of this model according to the indicators and outputs of the Amos software.

Table 4. Results of Testing the Model by Path Analysis

\begin{tabular}{lllllllllll}
\hline Model & $\mathbf{x}^{2}$ & $\mathbf{p}$ & $\mathbf{d f}$ & RMESA & $\mathbf{p}$ & GFI & IFI & NNFI & NFI & CFI \\
1 & 1.28 & $<.01$ & 1 & .027 & $<.05$ & .99 & .99 & .97 & .99 & .99 \\
\hline
\end{tabular}




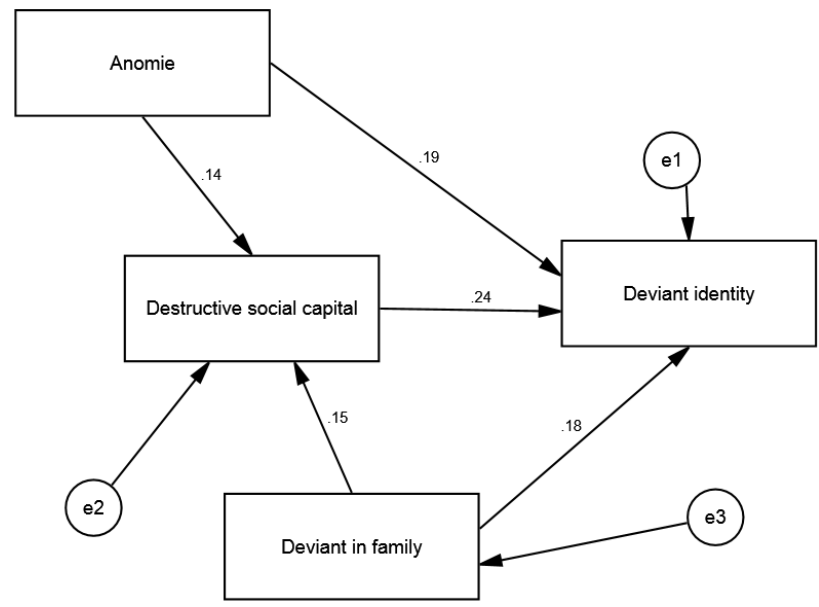

Fiqure 2: Path Analysis

Figure 1 and Table 2 show the total, direct and indirect effects of the independent variables on deviant identity using regression weights. Results indicate that most general effects are related to destructive social capital $(0.239)$, anomie $(0.225)$ and deviations in the family $(0.218)$. The deviation in family due to the destructive social capital, in addition to direct effects, has an indirect effect on the deviant identity; moreover, the anomie directly affects the destructive social capital and directly and indirectly affects the deviant identity.

Table 5. Direct and Indirect Coefficients

\begin{tabular}{llll}
\hline Variable & Direct Effect & Indirect Effect & Total Effect \\
\hline Destructive social capital & $.239^{* *}$ & .000 & $.239^{\star *}$ \\
Anomie & $.191^{* *}$ & $.034^{*}$ & $.225^{\star *}$ \\
Deviant in family & $.183^{* *}$ & $.035^{*}$ & $.218^{* *}$ \\
\hline
\end{tabular}

Note: ${ }^{* *}$ Correlation is significant at the 0.01 level (2-tailed)

${ }^{*}$ Correlation is significant at the 0.05 level (2-tailed).

\section{Discussion}

Deviant identity is one of the basic requisites for entering and repeating social deviances; so, this study was conducted to investigate the factors associated with the deviant identity among the prisoners. The results showed that there is a positive and significant relationship between destructive social capital and deviant identity. This result is consistent with those obtained by Fergusson et al. (2007), Boduszek et al. (2007) and Rocheleau and Chavez (2014). According to Sutherland, differential association with deviant people leads to formation of deviant identity and tendency for committing the crimes. If the individual social capital is affected by deviant people and groups it may lead to deviation and deviant identity. This variable can result in stretching the identity and deviant actions: destructive social capital among the criminals provide a secure network for continuing and repeating the crimes. In fact, having a network of relationships and mutual trust between criminals provides the ground for the reproduction and continuity of the criminal activities. In such a network, people support each other and for deviations, provide the mutual security.

Other results showed that anomie has a positive and significant relationship with deviant identity; this result is consistent with those results obtained by Zojonc (2013), Carter and Carter (2014) and Noriega (2014); all of these studies 
acknowledged the relationship between anomie and crime and deviations. According to Merton, in an anomic society, people cannot use legitimate means to reach their target; therefore, they tend towards deviancy.

Results also showed that there is a positive and significant relationship between the deviation of family and deviant identity; the results of the studies conducted by Shaw et al. (1991), Simons et al. (1991), Vazsonyi et al. (2007) and Abigail et al. (2010), indicated that family processes and parenting practices have direct and indirect effects on a person's crime. According to the theory of identity in symbolic interaction theory, a person in the family learn one of the core networks of socialization, values and norms, so, if these values and norms are deviant, the it may lead to the deviant identity.

\section{References}

[1] Abigail, F., Van Horn, M., Antaramian, S., Hawkins, D. (2010). How Do Families Matter? Age and Gender Differences in Family Influences on Delinquency and Drug Use. Journal of Youth violence and juvenile justice. $9(2), 150-170$.

[2] Becker, H. (1963). Outsiders: Studies in the sociology of deviance. New York, NY: McMillan.

[3] Boduszek, D., Adamson, G., Shevlin, M., Mallett, J., Hyland, P. (2012). Criminal Social Identity of Recidivistic Prisoners: The Role of Self-Esteem, Family and Criminal Friends. Journal of Police Crime Psychology, 28 (1), 15- 25.

[4] Carter, E., Carter, M. (2014). Anomie, Deviance, and the Religious Factor: Data from 104 NFL Players. Journal of Sociology and Social Work, 2 (2), 135-144.

[5] Ebaugh, H. (1988). Becoming an Ex: The Process of Role Exit. Chicago, IL: University of Chicago Press.

[6] Fergusson, M. D., Vitaro, F., Wanner, B., Brendgen, M. (2007). Protective and Compensatory Factors Mitigating the Influence of Deviant Friends on Delinquent Behaviours during Early Adolescence, Journal of Adolescence, 30, 33-50.

[7] Garfield, E. (1987). The Anomie-Deviant Behavior Connection: The Theories of Durkheim, Merton, and Srole. Essays of an Information Scientist ,10, 272 -281.

[8] Hattery, A., Smith, E. (2010). Prisoner Reentry and Social Capital. Maryland: Lexington Books.

[9] Irwin, J. (1977). Scenes. Beverly Hills, CA, Sage.

[10] Lemert, E. (1972). Human deviance, social problems, and social control (2nd ed). Englewood Cliffs, NJ: Prentice Hall.

[11] Link, B. (1982). Mental patient status, work, and income: An examination of the effects of a psychiatric label. American Sociological Review, 47, 201-215.

[12] Lofland, J. (1969). Deviance and Identity. Englewood Cliffs, NJ: Prentice-Hall.

[13] Matsueda, R. (1992). Reflected appraisals, parental labeling, and delinquency: specifying a symbolic interactionist theory. American Journal of Sociology, 97, 1577-611.

[14] Matsueda, R. L. (1992). Reflected appraisal, parental labeling, and delinquency: Specifying a symbolic interactionist theory. American Journal of Sociology, 97, 1577-1611.

[15] Meisenhelder, T. (1977). An Exploratory Study of Exiting From Criminal Careers. Criminology, 15, 319-34.

[16] Messner, S., Rosenfeld, R. (1997). Political Restraint of the Market and Level of Criminal Homicide: A Cross National Application of Institutional - Anomie Theory, The University of North Carolina Press,75, 1393 - 1416.

[17] Noriega J., Hernández, G., Zaragoza, M. (2014). Efectos de la anomia, alienación y confianza en la conducta antisocial en jóvenes fuera del sistema escolar y laboral. Civilizar 14 (27): 155-164, julio-diciembre de 2014.

[18] Rocheleau, G., Chavez, J. (2014). Guilt by Association: The Relationship between Deviant Peers and Deviant Labels. Journal of Deviant Behavior, 36 (3), 167-186.

[19] [Sampson, R., \& Laub, J. (1997). A life-course theory of cumulative disadvantage and the stability of delinquency. In Terrence Thornberry (Ed.), Developmental the- ories of crime and delinquency (pp. 133-161). New Brunswick, NJ: Transaction.

[20] Shaw, J. M., Scott W. A. (1991). Influence of parent discipline style on delinquent behaviour: the mediating role of control orientation. Australian journal of phychology, 43, 61-67.

[21] Shover, N. (1983). The Later Stages of Ordinary Property Offenders Careers. Social Problems, 31, 208-18.

[22] Simons, R. L., Whitbeck, L. B., Conger, R. D., Conger, K. (1991). Parenting factors, social skills, and value commitments as precursors to school failure, involvement with deviant peers and delinquent behaviour. Journal of Youth and Adolcensce, 20, 645-664. 
[23] Stryker, S., Burke, P. (2000). The past, present, and future of an identity theory. Social Psychology Quarterly, 63, 284-97.

[24] Sutherland, E., Cressy, D. (1966). Principles of Criminology. Philadelphia: University Press.

[25] Thompson, L. (2009). Australian film, young Lebanese-Australian men and the performance of identity. Bachelor dissertation, Dep. Sociology and Social Policy, Sydney Uni.

[26] Thornberry, T.P. (1987). Toward an interactional theory of delinquency. Criminology, 25, 863-92.

[27] Turner, J. H. (2003). The Structure of Sociological Theory. United State: Wadsworth, Seventh Edition.

[28] [Vazsonyi, A., Belliston, L. (2004). The family $\rightarrow$ low Self-control $\rightarrow$ deviance A Cross-Cultural and CrossNational Test of Self-Control Theory. Criminal justice and behavior, 34, 505-530.

[29] Walters, (2016). Proactive Criminal Thinking and Deviant Identity as Mediators of the Peer Influence Effect. Journal of youth violence and juvenile justice, 14, 1-18.

[30] Watson, C. M. (2007). Examining juvenile crime and recidivism. Master dissertation, Dep. Sociology, Uni. Marshall. Canada.

[31] Zojonc, A. (2013). Immigration and crime: is public opinion pragmatic? Pacific Sociological Association Annual Meeting. 